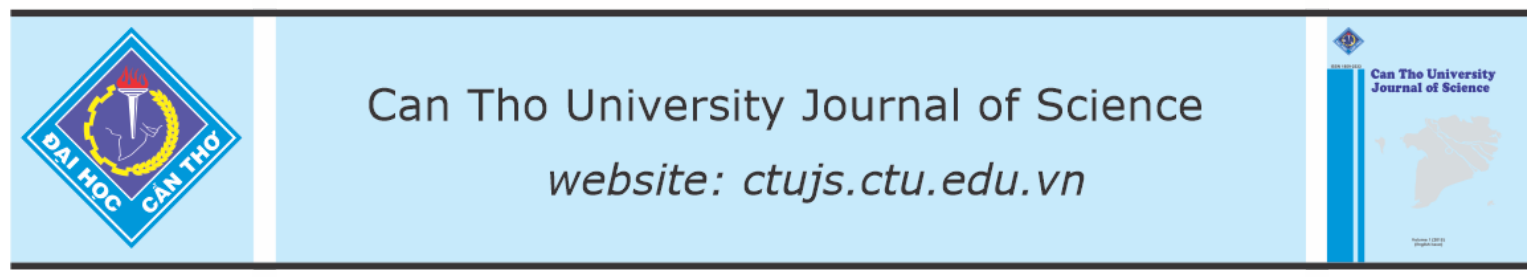

DOI: 10.22144/ctu.jen.2021.043

\title{
Primary investigating chemical constituents of bioactive extract from Centrostachys aquatica (R.Br.) Wall. ex Moq.-Tand.
}

Ngo Quoc Luan ${ }^{1 *}$, Ta Thao Cuong ${ }^{1}$, Tran Thi Manh Huynh ${ }^{1}$, Le Minh Dan ${ }^{1}$, Ngo Khac Khong Minh $^{2}$, Ngo Trong Nghia ${ }^{3}$, Nguyen Diep Xuan Ky ${ }^{4,5}$, Phan Nhat Minh ${ }^{4,5}$ and Nguyen Tan Phat ${ }^{4,5}$

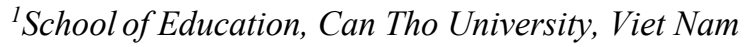

${ }^{2}$ Medical Faculty, Nam Can Tho University, Viet Nam

${ }^{3}$ Faculty of Environment and Natural Resource, Kien Giang University, Viet Nam

${ }^{4}$ Institute of Chemical Technology, Vietnam Academy of Science and Technology, Viet Nam

${ }^{5}$ University of Science and Technology, Vietnam Academy of Science and Technology, Viet Nam

*Correspondence: Ngo Quoc Luan (email:ngoquocluan@ctu.edu.vn)

\section{Article info.}

Received 21 Jul 2021

Revised 20 Aug 2021

Accepted 21 Oct 2021

\section{Keywords}

Antimicrobial activity, antioxidant activity,

Centrostachys aquatica, 20hydroxyecdysone, oleanolic acid, $\beta$-spinasterol

\begin{abstract}
This study is aimed to screen the biological activities and chemical composition to find evidences for potential medicinal applications of Centrostachys aquatica in the Mekong Delta. Crude methanol extract and subextracts in n-hexane, ethyl acetate, and acetone from Centrostachys aquatica were tested bioactivities. The methanol extract, n-hexane and ethyl acetate subextracts exhibited antimicrobial activity with corresponding MIC values of 200, 100 and $200 \mu \mathrm{g} / \mathrm{mL}$, respectively. The ethyl acetate subextract was inhibited cytotoxicity against cancer cell line $L U-1$ with ICso of $27.66 \mu \mathrm{g} / \mathrm{mL}$. None of the extracts showed antioxidant ability. Three known secondary metabolites including oleanolic acid (1), 20-hydroxyecdysone (2), and $\beta$-spinasterol (3) were isolated for the first time from the bioactive (ethyl acetate) subextract of Centrostachys aquatica. Their structures were elucidated by modern spectra as MS, NMR and comparison with published data.
\end{abstract}

\section{INTRODUCTION}

Centrostachys aquatica (R.Br.) Wall. ex Moq.Tand. or Achyranthes aquatica R.Br. (Ho, 1999) has a local name of "Cỏ Xước nước" in Vietnamese, it means "water scratch grass". It is only one aquatic species belonging to the genus Centrostachys in the family Amaranthaceae (Figure 1). 


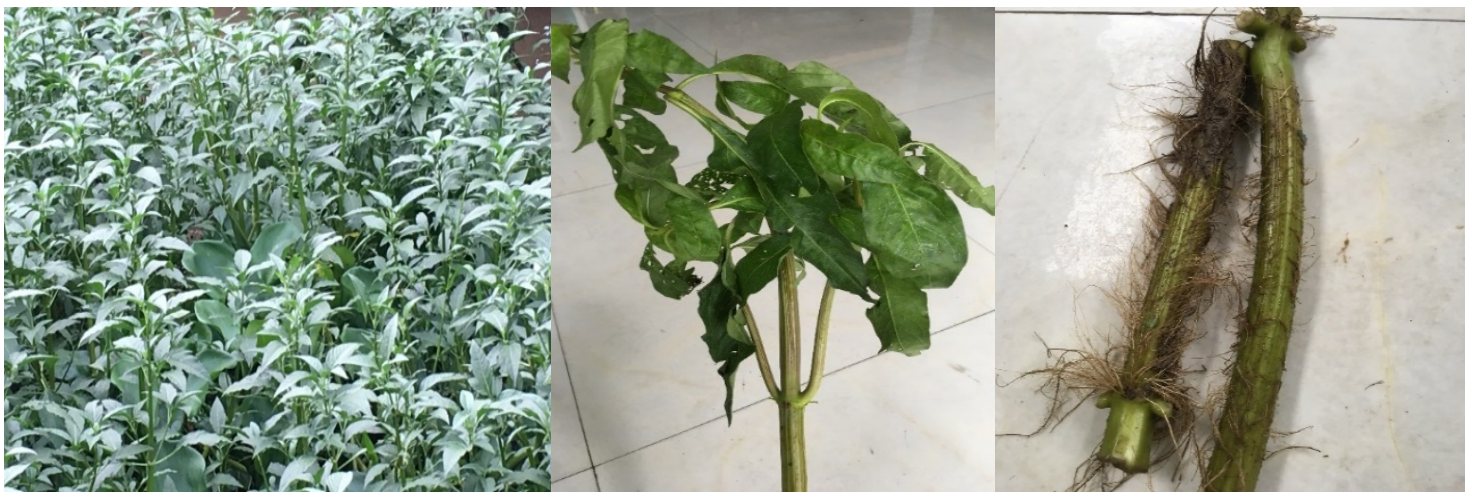

Figure 1. Centrostachys aquatica (R.Br.) Wall. ex Moq.-Tand.

In Viet Nam, Centrostachys aquatica distributed in wetlands such as swamps, alluvial flats along rivers and canals in the Mekong Delta. People use this plant as a kind of vegetable and there is no information about its use in traditional medicine.

In recently researched documents on Centrostachys aquatica were found, there was only one report about isolating a compound called loliolide; the aqueous methanol extract and loliolide from this extract both have the ability to inhibit the growth of roots and hypocotyls of cress (Lepidium sativum) (Bich \& Kato-Noguchi, 2014). This could be the basis for a convincing explanation for phytotoxicity and allelopathic activity of Centrostachys aquatica.

To find out if Centrostachys aquatica had other beneficial activities, extracts from this plant were tested some of the bioactivities. The results showed that the ethyl acetate extract has good antimicrobial and cytotoxic activity against lung cancer cells (section 3.1). This is also the reason for studying the chemical composition of this bioactive extract with three natural compounds were initially isolated.

\section{EXPERIMENT}

\subsection{Plant material}

The whole plants of Centrostachys aquatica were collected in Can Tho city in May, 2021. Voucher specimens have been identified at Deparment of Biology, School of Education, Can Tho University. After cleaning, poor quality parts were removed. Good material was dried at $50^{\circ} \mathrm{C}$ in order to decrease the humidity to less than $2 \%$, followed by crushing into fine powder.

\subsection{General experimental procedures}

\subsubsection{Extraction and purification}

Solid-liquid extractions were used with methanol, $n$ hexane, ethyl acetate and acetone. Solvent evaporating was accomplished by using RE-52A rotary evaporator system (China).

Thin layer chromatography (TLC) was carried out on pre-coasted silica gel $60 \mathrm{~F}_{254}(0.25 \mathrm{~mm})$ aluminium sheet (Merck). Traces of compounds were detected by illuminating under UV light $(254 / 365 \mathrm{~nm})$ or spraying $10 \% \mathrm{H}_{2} \mathrm{SO}_{4}$ solution in ethanol and then heating at $105^{\circ} \mathrm{C}$ for $1-2 \mathrm{~min}$ on electric stove.

For common phase column chromatography (CP$\mathrm{CC})$, silica gel 60 (0.040-0.063 mm, Merck), increasing polarity solvent systems including $n$ hexane $(\mathrm{H})$, chloroform $(\mathrm{C})$, ethyl acetate $(\mathrm{E})$ and methanol (M) was used. Compounds were purified by re-crystallization in pure solvents.

\subsubsection{Structural elucidation and identification}

Melting point (mp.) was recorded by a melting point meter (Electrothermal 9100, UK), using capillary at Can Tho University. ${ }^{1} \mathrm{H}-\mathrm{NMR},{ }^{13} \mathrm{C}-\mathrm{NMR}$, DEPT, HSQC, COSY, HMBC spectra were recorded on a Bruker AM500, 600 FT-NMR spectrometer; Mass spectrum (MS) was recorded on mass spectrometer (HP 1100 series, LC/MSD Trap, Agilent) at Vietnam Academy of Science and Technology.

\subsubsection{Antimicrobial, cytotoxic and antioxidant activity testing}

Biological activity assays were conducted at the Experimental Biology Department, Institute of Chemistry of Natural Compounds, Vietnam Academy of Science and Technology.

The antimicrobial activity assay was followed the disc diffusion agar method of Vanden-Berghe and Vlietinck (1991), Mckane and Kandel (1996), improved by using 96-well microplate and ELISA reader. 
The cytotoxic activity assay was performed according to the method of Skehan et al. (1990) and Likhiwitayawuid and Angerhofer (1993) has been applied at the USA National Cancer Institute (NCI) and the College of Pharmacy, University of Illinois, Chicago, USA.

The antioxidant activity assay was based on its ability to trap free radicals generated by 1,1 diphenyl-2-picrylhydrazyl (DPPH) of BrandWilliams et al. (1995), Shela et al. (2003) and Kumar et al. (2013).

\subsection{Extraction and isolation}

The dried plant powder $(7.0 \mathrm{~kg})$ was exhaustedly extracted with methanol $70 \% \mathrm{vol}(>20 \mathrm{~L})$ and then evaporated under reduce pressure to remove the solvent to give dry dark-green residue of crude methanol extract (CAMe, $305 \mathrm{~g}$ ).

The CAMe extract (300 g) was distributed with $n$ hexane $(10 \mathrm{~L})$, ethyl acetate $(15 \mathrm{~L})$, and acetone $(10$ $\mathrm{L})$, respectively, and the solvents were evaporated under poor pressure to obtain subextracts $\mathrm{CAHe}$ (50.6 g), CAEt (93.7 g), CAAc (40.3 g) and the remainder was insoluble in distributed solvents (CAW, $101 \mathrm{~g}$ ).

The CAEt subextract ( $90 \mathrm{~g}$ ) was subjected to CP-CC with $\mathrm{H}: \mathrm{E}$ (gradient, 0 to $100 \% \mathrm{E}$ ) and final with $\mathrm{E}: \mathrm{M}$ (9:1) solvent mixtures as eluent to give 7 fractions (CAE1-7).

The fraction CAE2 (H:E 8:2; $13.12 \mathrm{~g}$ ) was treated with CP-CC (H:E, gradient, 0 to $100 \% \mathrm{E}$ ) to afford 6 subfractions (CAE2.1-2.6). The subfraction CAE2.4 (H:E 85:15, $3.45 \mathrm{~g}$ ) was continued to take CP-CC (C:M, gradient, 0 to $100 \% \mathrm{M}$ ) to get 5 subfractions (CAE2.4.1-2.4.5). The subfraction CAE2.4.3 (C:M 95:5, 0.55 g) was washed with H:E 9:1 and then re-crystallized in methanol to produce compound 1 (10.1 mg).

The fraction CAE5 (H:E 25:75, $23.52 \mathrm{~g}$ ) was performed CP-CC with $\mathrm{H}: \mathrm{E}$ solvent systems (from
5:5 to $25: 75$, ending with methanol) to afford 6 subfractions (CAE5.1-5.6). The subfraction CAE5.2 (H:E 5:5, $4.21 \mathrm{~g}$ ) was cleaned up by E:M 9:1 and recrystallized two times in methanol to yield compound 2 (7.2 mg).

The fraction CAE1 (H:E 9:1; $8.34 \mathrm{~g}$ ) was taken CP$\mathrm{CC}$ with eluent of $\mathrm{H}: \mathrm{E}$ (gradient, 0 to $100 \% \mathrm{E}$ ) to give 6 subfractions (CAE1.1-1.6). The subfraction CAE1.4 (H:E 9:1, $1.42 \mathrm{~g}$ ) was continued to perform CP-CC with H:E $95: 5$ to get 4 subfractions (CAE1.4.1-1.4.4). The subtraction CAE1.4.2 (H:E $95: 5,0.12 \mathrm{~g})$ was re-crystallized in $n$-hexane to obtain compound $\mathbf{3}$ (9.2 $\mathrm{mg}$ ).

\subsection{Physical characteristic and spectral data}

Oleanolic acid (1): A white amorphous powder, $\mathrm{mp} .306-308^{\circ} \mathrm{C}$, lotus purple chromatographic stain, no luminescence under UV lamp. ESI-MS $\mathrm{m} / z 455$ [M-H] ;. ${ }^{1} \mathrm{H}-\mathrm{NMR}\left(\mathrm{CDCl}_{3}, 600 \mathrm{MHz}, \delta_{H} \mathrm{ppm}, J \mathrm{~Hz}\right)$ and ${ }^{13} \mathrm{C}-\mathrm{NMR}\left(\mathrm{CDCl}_{3}, 150 \mathrm{MHz}, \delta_{C} \mathrm{ppm}\right)$ (Table 4).

20-hydroxyecdysone (2): White needle-shaped crystals, mp. $242-244^{\circ} \mathrm{C}$, purple pink TLC stain, luminescence under UV lamp. ESI-MS $\mathrm{m} / \mathrm{z} 481$ $[\mathrm{M}+\mathrm{H}]^{+}$; . ${ }^{1} \mathrm{H}-\mathrm{NMR}$ (DMSO-d $6,500 \mathrm{MHz}, \delta_{H} \mathrm{ppm}$, $J \mathrm{~Hz}$ ) and ${ }^{13} \mathrm{C}-\mathrm{NMR}$ (DMSO-d $6,125 \mathrm{MHz}, \delta_{C} \mathrm{ppm}$ ) (Table 4).

$\beta$-Spinasterol (3): White needle-shaped crystals, mp. $164-166^{\circ} \mathrm{C}$, red purple TCL stain, no luminescence under UV lamp. ESI-HRMS $\mathrm{m} / \mathrm{z}$ $395.3689\left[\mathrm{M}-\mathrm{H}_{2} \mathrm{O}+\mathrm{H}\right]^{+}$; ${ }^{1} \mathrm{H}-\mathrm{NMR}\left(\mathrm{CDCl}_{3}, 500\right.$ $\left.\mathrm{MHz}, \delta_{H} \mathrm{ppm}, J \mathrm{~Hz}\right)$ and ${ }^{13} \mathrm{C}-\mathrm{NMR}\left(\mathrm{CDCl}_{3}, 125\right.$ $\mathrm{MHz}, \delta_{C} \mathrm{ppm}$ ) (Table 4).

\section{RESULTS AND DISCUSSIONS}

\subsection{Bioactivities of extracts}

Results of antimicrobial activity, anticancer and antioxidant activities of 4 extracts from Centrostachys aquatica were presented in Table 1, 2 and 3, respectively. 
Table 1. Results of antimicrobial activity of extracts from Centrostachys aquatica

\begin{tabular}{|c|c|c|c|c|c|c|c|}
\hline \multirow{3}{*}{ No. } & \multirow{3}{*}{ Code } & \multirow{3}{*}{$\begin{array}{c}\text { Initial } \\
\text { concentration } \\
(\mu \mathrm{g} / \mathrm{mL})\end{array}$} & \multicolumn{4}{|c|}{ Minimum inhibitory concentration $(\mathrm{MIC}, \mu \mathrm{g} / \mathrm{mL})$} & \multirow{3}{*}{ Comments } \\
\hline & & & \multicolumn{2}{|c|}{ Gram (-) Bacteria } & \multicolumn{2}{|c|}{ Gram $(+)$ Bacteria } & \\
\hline & & & $\begin{array}{c}\text { Escherichia } \\
\text { coli }\end{array}$ & $\begin{array}{c}\text { Pseudomonas } \\
\text { aeruginosa }\end{array}$ & $\begin{array}{l}\text { Bacillus } \\
\text { subtillis }\end{array}$ & $\begin{array}{c}\text { Staphylococcus } \\
\text { aureus }\end{array}$ & \\
\hline & (-)-Control & & $(-)$ & $(-)$ & $(-)$ & $(-)$ & \\
\hline 1 & CAAc & 400 & $(-)$ & $(-)$ & $(-)$ & $(-)$ & Negative \\
\hline 2 & CAHe & 400 & $(-)$ & $(-)$ & 100 & $(-)$ & $\begin{array}{l}\text { Positive } \\
\text { (1 strain) }\end{array}$ \\
\hline 3 & CAMe & 400 & $(-)$ & $(-)$ & 200 & $(-)$ & $\begin{array}{l}\text { Positive } \\
\text { (1 strain) }\end{array}$ \\
\hline 4 & CAEt & 400 & $(-)$ & $(-)$ & 200 & $(-)$ & $\begin{array}{l}\text { Positive } \\
\text { (1 strain) }\end{array}$ \\
\hline
\end{tabular}

It can be seen from the Table 1 that CAHe, CAMe and CAEt samples exhibited resistance to the test strain of B. subtilis with MIC values of 100, 200 and
$200 \mu \mathrm{g} / \mathrm{mL}$, respectively. The CAAc extract was completely negative for 4 tested microorganism strains.

Table 2. Results of anticancer activity of extracts from Centrostachys aquatica

\begin{tabular}{|c|c|c|c|c|c|c|}
\hline \multirow[t]{2}{*}{ No. } & \multirow[t]{2}{*}{ Code } & \multirow{2}{*}{$\begin{array}{c}\text { Initial } \\
\text { concentration } \\
(\mu \mathrm{g} / \mathrm{mL})\end{array}$} & \multicolumn{2}{|c|}{$\begin{array}{c}\text { Cell survival rate (CS value, \%) } \\
\text { Cell trains }\end{array}$} & \multicolumn{2}{|c|}{$\begin{array}{l}\text { IC }_{50} \text { value }(\boldsymbol{\mu g} / \mathbf{m L}) \\
\text { Cell trains }\end{array}$} \\
\hline & & & Hep-G2 & $\begin{array}{r}\text { LU-1 } \\
\end{array}$ & Hep-G2 & LU-1 \\
\hline & DMSO & - & 100 & 100 & - & - \\
\hline & (+) Control & 5 & $3,14 \pm 0,71$ & $1,89 \pm 0,60$ & 0,32 & 0,27 \\
\hline 1 & CAAc & 40 & $98,88 \pm 1,09$ & $88,15 \pm 1,64$ & - & - \\
\hline 2 & CAHе & 40 & $63,59 \pm 2,04$ & $66,39 \pm 0,51$ & - & - \\
\hline 3 & CAMe & 40 & $93,48 \pm 2,25$ & $93,38 \pm 1,62$ & - & - \\
\hline 4 & CAEt & 40 & $53,36 \pm 1,52$ & $40,49 \pm 0,48$ & - & 27,66 \\
\hline
\end{tabular}

As the results in Table 2, only the sample CAEt showed inhibitory activity on LU-1 cell line (lung cancer) with $\mathrm{IC}_{50}$ value of $27.66 \mu \mathrm{g} / \mathrm{mL}$. The remaining samples did not show cytotoxic activity of 2 cancer cell lines including Hep-G2 (liver cancer) and LU-1 at the tested concentration.

Table 3. Results of antioxidant activity of extracts from Centrostachys aquatica

\begin{tabular}{llcccc}
\hline No. & Code & $\begin{array}{c}\text { Initial concentration } \\
(\boldsymbol{\mu g} / \mathbf{m L})\end{array}$ & $\begin{array}{c}\text { Scavenging capacity } \\
(\mathbf{S C}, \mathbf{\%})\end{array}$ & $\begin{array}{c}\text { A half scavenging } \\
\text { concentration } \\
\left(\mathbf{S C}_{\mathbf{5 0}}, \boldsymbol{\mu g} / \mathbf{m L}\right)\end{array}$ & Comments \\
\hline & $(+)$ Control & $\mathbf{5 0}$ & $\mathbf{7 9 , 2 4 \pm \mathbf { 1 , 0 2 }}$ & $\mathbf{1 2 , 0 2}$ & Positive \\
& $(-)$ Control & - & 0 & - & Negative \\
1 & CAAc & 200 & $12,21 \pm 2,01$ & - & Negative \\
2 & CAHe & 200 & $10,98 \pm 0,41$ & - & Negative \\
3 & CAMe & 200 & $11,40 \pm 0,66$ & - & Negative \\
4 & CAEt & 200 & $24,63 \pm 1,50$ & - & Negative \\
\hline
\end{tabular}

(-) Control: DPPH/EtOH + DMSO.

Table 3 showed the test samples did not exhibit antioxidant activity on the DPPH system at the test concentrations.

In summary, the bioactivity assay showed that the CAEt extract was the most active of the tested extracts. So this extract was chosen to investigate its chemical composition.
(+) Control: DPPH/EtOH + ascorbic acid.

\subsection{Chemical structure elucidation of isolated compounds}

Three isolated compounds had some similar characteristics as being white solids, no producing positive reaction to $\mathrm{FeCl}_{3}$ reagent; it can be inferred that they do not belong to the group of phenolic substances. Typical signals of protons and carbons 
in 1D-NMR showed that they had the patterns of triterpene and sterol backbones.

\subsubsection{Compound 1}

Compound 1 was obtained as a white amorphous powder, its $\mathrm{mp}$. was about $306-308^{\circ} \mathrm{C}$. It had lotus purple chromatographic spot and no luminescence under UV lamp.

The molecular formula of compound $\mathbf{1}$ was speculated to be $\mathrm{C}_{30} \mathrm{H}_{48} \mathrm{O}_{3}$ (456 amu, seven degrees of unsaturation) on the basis of ESI-MS $(\mathrm{m} / \mathrm{z} 455$ $\left.[\mathrm{M}-\mathrm{H}]^{-}\right)$.

The ${ }^{1} \mathrm{H}-\mathrm{NMR}$ spectrum of compound 1 revealed 7 singlet signals of methyl protons at $\delta_{H}[0.76(3 \mathrm{H}, s)$, $0.77(3 \mathrm{H}, s), 0.90(3 \mathrm{H}, s), 0.91(3 \mathrm{H}, s), 0.93(3 \mathrm{H}, s)$, $0.99(3 \mathrm{H}, s)$ and $1.13(3 \mathrm{H}, s)]$; one oxygenated methine proton at $\delta_{H} 3.22(1 \mathrm{H}, d d, 11.4,4.2)$; one double-bonded methine proton at $\delta_{H} 5.28(1 \mathrm{H}, t, 3.6)$ and about 25 other protons of methine, methylene, hydroxyl groups (Table 4).

The ${ }^{13} \mathrm{C}$-NMR and DEPT spectra of compound $\mathbf{1}$ appeared signals of total 30 carbons including 7 methyl, 10 methylene, 5 methine and 8 quaternary carbons. In which, 2 carbons at $\delta_{C} 122.7$ and 143.6 exhibited the presence of a double bond; carbon at $\delta_{C} 182.8$ allowed to predict having a carboxylic group; and carbon at $\delta_{C} 79.1$ was oxygenated methine group (Table 4).

From mentioned 1D-NMR data, compound 1 gave the characteristic spectra pattern of a pentacyclic triterpene. Based on the spectral data analysis, comparison with those given in the literature (Zuhal et al., 2009) and checking with its own 2D-NMR spectra, compound $\mathbf{1}$ was identified as oleanolic acid (Figure 2).

Oleanolic acid could be used to prevent the majority of the most common diseases of civilization i.e. cancer, cardiovascular diseases, atherosclerosis or diabetes (Paszel-Jaworska et al., 2014).

\subsubsection{Compound 2}

Compound 2 was isolated as white needle-shaped crystals, its mp. was about $242-244^{\circ} \mathrm{C}$. It had purple pink TLC stain and luminescence under UV lamp, that proved there was a conjugate system in its chemical structure.

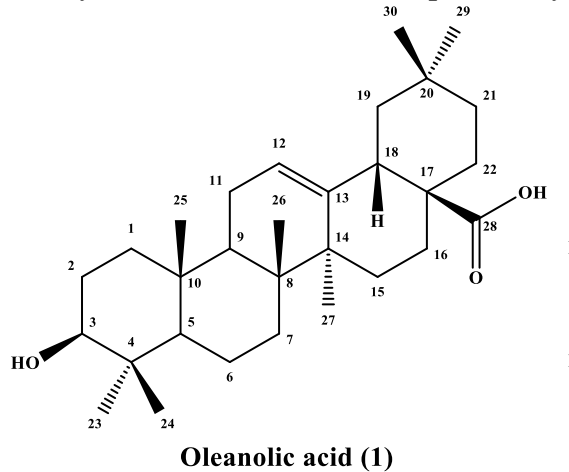<smiles>CC[C@H](/C=C/[C@@H](C)[C@@]1(C)CC[C@@]2(C)C3=CC[C@]4(C)C[C@@H](O)CC[C@]4(C)[C@@]3(C)CC[C@@]21C)C(C)C</smiles>

Figure 2. Chemical structures of isolated compounds

The molecular formula of compound $\mathbf{2}$ was established as $\mathrm{C}_{27} \mathrm{H}_{44} \mathrm{O}_{7}$ (480 amu, six degrees of unsaturation) by ESI-MS $\left(m / z 481.1[\mathrm{M}+\mathrm{H}]^{+}\right)$.
${ }^{1} \mathrm{H}-\mathrm{NMR}$ spectrum of compound $\mathbf{2}$ appeared typical proton signals of 5 methyl groups at $\delta_{H}[0.76(3 \mathrm{H}$, $s), 0.84(3 \mathrm{H}, s), 1.06(6 \mathrm{H}, s)$, and $1.08(3 \mathrm{H}, s)] ; 3$ oxygenated methine proton at $\delta_{H}[3.12(1 \mathrm{H}, d, 5.0)$, 
$3.56(1 \mathrm{H}, s)$, and $3.77(1 \mathrm{H}, s)]$; one double-bonded methine proton at $\delta_{H} 5.63(1 \mathrm{H}, s)$ and about 25 other protons of methine, methylene, hydroxyl groups (Table 4).

${ }^{13} \mathrm{C}-\mathrm{NMR}$ and DEPT spectra exhibited signals of total 27 carbons containing 5 methyl, 8 methylene, 7 methine and 7 quaternary carbons. There were figurative signals as one ketone carbon at $\delta_{C}$ 202.6; 6 oxygenated methine and quaternary carbons at $\delta_{C}$ [66.6, 66.7, 68.7, 75.7, 76.2 and 82.9]; 5 methyl carbons at $\delta_{C}[17.1,20.9,23.8,29.0$ and 29.9]. In addition, methine carbon at $\delta_{C} 120.4$ and quaternary carbon at $\delta_{C} 165.2$ confirmed the presence of a $\mathrm{C}=\mathrm{C}$ double bond (Table 4).

With the above analyzed spectral characteristics, it is possible to predict compound $\mathbf{2}$ belonging to the steroid group. The 1D-NMR spectral data of compound 2 were similar to those of 20-

Table 4. 1D-NMR spectral data of isolated compounds

\begin{tabular}{|c|c|c|c|c|}
\hline \multirow{2}{*}{ C-position } & Compound 1 & \multirow[t]{2}{*}{ Compound 2} & \multicolumn{2}{|l|}{ Compound 3} \\
\hline & ${ }^{1} \mathrm{H}$ & & ${ }^{13} \mathrm{C}^{1} \mathrm{H}$ & ${ }^{13} \mathrm{C}$ \\
\hline 1 & $1.60,0.95$ & $38.41 .59,1.29$ & $36.61 .09,1.82$ & 37.2 \\
\hline 2 & $1.75,1.56$ & $27.23 .56(1 \mathrm{H}, s)$ & $66.71 .39,1.77$ & 31.5 \\
\hline 3 & $3.22(1 \mathrm{H}, d d, 11.4,4.2)$ & $79.13 .77(1 \mathrm{H}, s)$ & $66.63 .56-3.62(1 \mathrm{H}, m)$ & 71.1 \\
\hline 4 & & $38.81 .57,1.48$ & $31.51 .27,1.70$ & 38.0 \\
\hline 5 & $0.73(1 \mathrm{H}, s)$ & $55.22 .20(1 \mathrm{H}, d d, 13.0,30.0)$ & 50.11 .40 & 40.3 \\
\hline 6 & $1.52,1.33$ & 18.3 & $202.61 .22,1.74$ & 29.7 \\
\hline 7 & $1.43,1.29$ & $32.65 .63(1 \mathrm{H}, s)$ & $120.45 .15(1 \mathrm{H}$, brs $)$ & 117.5 \\
\hline 8 & & 39.3 & 165.2 & 139.6 \\
\hline 9 & 1.54 & $47.63 .01(1 \mathrm{H}, s)$ & 33.11 .65 & 49.5 \\
\hline 10 & & 37.1 & 37.6 & 34.2 \\
\hline 11 & $1.89,1.87$ & $23.41 .86,1.64$ & 20.01 .48 & 21.6 \\
\hline 12 & $5.28(1 \mathrm{H}, t, 3.6)$ & $122.71 .79,1.52$ & $30.31 .99,2.02$ & 39.5 \\
\hline 13 & & 143.6 & 46.8 & 43.3 \\
\hline 14 & & 41.6 & 82.91 .81 & 55.1 \\
\hline 15 & $1.13,1.06$ & $27.72 .01(1 \mathrm{H}, d, 8.5), 1.72$ & $30.81 .40,1.52$ & 23.0 \\
\hline 16 & $1.95,1.99$ & $23.01 .62(2 \mathrm{H})$ & 20.21 .25 & 28.5 \\
\hline 17 & & $46.52 .26(1 \mathrm{H}, t, 8.5)$ & 48.71 .25 & 55.9 \\
\hline 18 & $2.82(1 \mathrm{H}, d d, 9.6,4.2)$ & $41.00 .84(3 \mathrm{H}, s)$ & $23.80 .81(3 \mathrm{H}, s)$ & 13.0 \\
\hline 19 & $1.64,1.18$ & $45.90 .76(3 \mathrm{H}, s)$ & $17.10 .55(3 \mathrm{H}, s)$ & 12.1 \\
\hline 20 & & 30.7 & 75.72 .04 & 40.8 \\
\hline 21 & $1.38,1.24$ & $33.81 .06(3 \mathrm{H}, s)$ & $20.91 .03(3 \mathrm{H}, d, 6.5)$ & 21.4 \\
\hline 22 & $1.78,1.55$ & $32.43 .12(1 \mathrm{H}, d, 5.0)$ & $76.25 .17(1 \mathrm{H}, d d, 15.0,8.5)$ & 138.2 \\
\hline 23 & $0.99(3 \mathrm{H}, s)$ & $28.11 .50,1.12$ & $26.15 .03(1 \mathrm{H}, d d, 15.0,8.5)$ & 129.5 \\
\hline 24 & $0.77(3 \mathrm{H}, s)$ & $15.61 .66,1.24$ & 41.41 .55 & 51.3 \\
\hline 25 & $0.91(3 \mathrm{H}, s)$ & 15.3 & 68.71 .55 & 31.9 \\
\hline 26 & $0.76(3 \mathrm{H}, s)$ & $17.11 .08(3 \mathrm{H}, s)$ & $29.90 .85(3 \mathrm{H}, d, 6.5)$ & 21.1 \\
\hline 27 & $1.13(3 \mathrm{H}, s)$ & $25.91 .06(3 \mathrm{H}, s)$ & $29.00 .82(3 \mathrm{H}, s)$ & 19.0 \\
\hline 28 & & 182.8 & $1.18,1.42$ & 25.4 \\
\hline 29 & $0.90(3 \mathrm{H}, s)$ & 33.1 & $0.80(3 \mathrm{H}, t, 2.0)$ & 12.2 \\
\hline 30 & $0.93(3 \mathrm{H}, s)$ & 23.6 & & \\
\hline
\end{tabular}

Note: Compounds 1 and 3 were recorded in $\mathrm{CDCl}_{3}$; compound 2 was recorded in DMSO-d . hydroxyecdysone (Figure 2) given in the literature (Vokac et al., 1998). Moreover, all correlation signals between protons and carbons in HSQC and HMBC spectral data of compound 2 conformed with the mentioned chemical structure, so compound $\mathbf{2}$ was determined to be 20 hydroxyecdysone.

A special available activity of 20-hydroxyecdysone was reducing moult cycle duration of the edible freshwater crab Travancoriana schirnerae (Raghavan and Ayanath, 2019).

\subsubsection{Compound 3}

Compound 3 was also received as white needleshaped crystals, its $\mathrm{mp}$. was $164-166^{\circ} \mathrm{C}$. It had red purple TCL spot and no luminescence under UV light. 
The molecular formula of compound $\mathbf{3}$ was speculated to be $\mathrm{C}_{29} \mathrm{H}_{48} \mathrm{O}$ (412 amu, six degrees of unsaturation) on the basic of ESI-HRMS $\mathrm{m} / \mathrm{z}$ $395.3689\left[\mathrm{M}-\mathrm{H}_{2} \mathrm{O}+\mathrm{H}\right]^{+}$.

Most of 1D-NMR spectral signals of compound 3 were similar to those of compound 2 (Table 4). However, compound $\mathbf{3}$ had two carbons (one methyl group) more than compound $\mathbf{2}$. There were only one oxygenated methine group at $\delta_{C} 71.1$ and with it the disappearance of the carbonyl group (Table 4).

Spectral data of compound 3 were compared with those given in the literature (Ragasa and Lim, 2005), 2D-NMR spectra of $\mathbf{3}$ were also used to check the fit of the predicted structure. As a result, compound 3 was identified as $\beta$-spinasterol (Figure 2).

$\beta$-Spinasterol was well evaluated its antiproliferative activity against human cancer cell lines HeLa and murine cancer cell line RAW 264.7 (Meneses-Sagrero et al., 2017).

\section{CONCLUSIONS}

Extracts from the whole plant of Centrostachys aquatica collected in Can Tho city were tested

\section{REFERENCES}

Bich, T. T. N., \& Kato-Noguchi, H. (2014). Isolation and identification of a phytotoxic substance from the emergent macrophyte Centrostachys aquatica. Botanical Studies, 55(59), 1-5. https://doi.org/10.1186/s40529-014-0059-1

Brand-Williams, W., Cuvelier, M. E., \& Berset, C. (1995). Use of a free radical method to evaluate antioxidant activity. L.W.T. Food Science and Technology, 28(1), 25-30. https://doi.org/10.1016/S0023-6438(95)80008-5

Ho, P. H. (1999). “Vietnamese plants”- An illustrated flora of Vietnam. Tre Publisher (in Vietnamese).

Kumar, G. P., Navyaa, K., Ramya, E. M., Venkataramana, M., Anand, T., \& Anilakumar, K. R. (2013). DNA damage protecting and free radical scavenging properties of Terminalia arjuna bark in PC-12 cells and plasmid DNA. Free Radicals and Antioxidants, 3, 35-39. https://doi.org/10.1016/j.fra.2013.04.001

Likhitayawuid, K., \& Angerhofer, C. K. (1993). Cytotoxic and antimalarial bisbenzylisoquinoline alkaloids from Sephania evecta. Jounal of Natural Products, 56(1), 30-38. https://doi.org/10.1021/np50091a005

Mckane, L., \& Kandel J. (1996). Microbiology Essentials and Applications (2 ${ }^{\text {nd }}$ ed.). McGraw-Hill Companies. bioactivity towards human applications and studied chemical components for the first time.

The CAEt extract exhibited resistance to the test strain of B. subtilis, inhibited for LU-1 cell line. $\mathrm{CAHe}$ and CAMe extracts showed resistance to the test strain of B. subtilis. Other above-declared experiments were negative.

Oleanolic acid, 20-hydroxyecdysone and $\beta$ spinasterol were isolated for the first time from CAEt extract of Centrostachys aquatica.

The interesting result was ability to inhibit human lung cancer cell of CAEt extract. Therefore, it is necessary to further isolate and test the anticancer activity of the purified compounds from this extract in order to be used as a medicinal plant. This research is still going on; the next results will be published as soon as possible.

\section{ACKNOWLEDGMENT}

This study is funded by the Can Tho University, project code T2021-110. The authors also thank Dang Minh Quan for plant identification.

Meneses-Sagrero, S. E., Navarro-Navarro, M., RuizBustos, E., Del-Toro-Sánchez, C. L., JiménezEstrada, M., \& Robles-Zepeda, R. E. (2017). Antiproliferative activity of spinasterol isolated of Stegnosperma halimifolium (Benth, 1844). Saudi Pharmaceutical Journal, 25(8), 11371143. https://doi.org/10.1016/j.jsps.2017.07.001

Paszel-Jaworska, A., Romaniuk, A., \& Rybczynska, M. (2014). Molecular Mechanisms of Biological Activity of Oleanolic Acid - A Source of Inspiration for A New Drugs Design. Mini-Reviews in Organic Chemistry, 11(3), 330-342. https://doi.org/10.2174/1570193X1103140915111839

Ragasa, C. Y., \& Lim, K. (2005). Sterols from Cucurbita maxima. Philippine Journal of Science, 134(2), 83-87.

Raghavan, S. D. A., \& Ayanath, A. (2019). Effect of 20$\mathrm{OH}$ ecdysone and methyl farnesoate on moulting in the freshwater crab Travancoriana schirnerae. Invertebrate Reproduction \& Development, 1-10. https://doi.org/10.1080/07924259.2019.1653387

Shela, G., Ratiporn, H., Yong-Seo, P., Soon-Teck, J., Zofia, Z., Zenon, J., Elena, K., Simon, T., \& Olga, M. B. (2004). Bioactive compounds and antioxidant potential in fresh and dried Jaffa sweeties, a new kind of citrus fruit. Journal of the Science of Food and Agriculture, 84, 1459-1463. https://doi.org/10.1002/jsfa. 1800

Skehan, P., Storeng, R., Scudiero, D., Monks, A., McMahon, J., Vistica, D., ... \& Boyd, M. R. 
(1990). New colorimetric cytotoxicity assay for anticancer-drug screening. JNCI Journal of the National Cancer Institute, 82(13), 1107-

1112. https://doi.org/10.1093/jnci/82.13.1107

Vanden Berghe, D. A., \& Vlietinck, A. J. (1991).

Screening methods for antibacterial and antiviral agents from higher plants. In K. Hostettmann (ed.), Methods in Plant Biochemistry, Vol. 6, Assays for Bioactivity, Academic Press, London (pp. 47-69).
Vokac, K., Budesnsky, M., Harmatha, J., \& Kohoutova, J. (1998). Ecdysteroid constituents of the mushroom Tapinella panuoides. Phytochemistry, 49(7), 21092114. https://doi.org/10.1016/S0031-9422(98)00448-8

Zuhal, G., Hilal, O., Ay, se K., Cavit K., \& Omur, L. D. (2009). Secondary metabolites from Nepeta heliotropifolia. Turk Journal of Chemistry, 33, 667-675. 